\title{
The Effect of Fasting and Refeeding on the Composition and Synthesis of Triacylglycerols, Phosphatidylcholines, and Phosphatidylethanolamines in Rat Liver
}

\author{
J. E. M. GROENER, W. KLEIN, AND L. M. G. VAN GOLDE ${ }^{1}$ \\ Laboratory of Veterinary Biochemistry, State University of Utrecht, Biltstraat 172, \\ 3572 BP Utrecht, The Netherlands
}

Received May 10, 1979; revised July 9, 1979

\begin{abstract}
Refeeding a high-sucrose, fat-free diet to fasted rats caused drastic alterations in the fatty acid composition of hepatic diacylglycerols, triacylglycerols, and phosphatidylcholines. However, the fatty acid profile of phosphatidylethanolamines did not change significantly. These results suggest that the fatty acid composition of diacylglycerols may influence the distribution of diacylglycerols among triacylglycerols, phosphatidylcholines, and phosphatidylethanolamines. Fasting and refeeding also affected the activities in vitro of a number of enzymes responsible for the formation of triacylglycerols, phosphatidylcholines, and phosphatidylethanolamines. The activity of hepatic phosphatidate phosphatase increased fourfold upon refeeding. However, fasting the rats did not affect the activity of this enzyme despite the reduced triacylglycerol synthesis in the fasted liver in vivo. Fasting and refeeding induced alterations in the activities of diacylglycerol acyltransferase, cholinephosphotransferase, and ethanolaminephosphotransferase which correlated reasonably well with the changes observed in the synthesis of triacylglycerols, phosphatidylcholines, and phosphatidylethanolamines in vivo, although the changes in diacylglycerol acyltransferase were too moderate. The changes in the activity of cholinephosphate cytidylyltransferase, which is suggested to catalyze the rate-limiting step in the formation of CDP-choline, ran parallel with the alterations in the synthesis of phosphatidylcholines in vivo. No such correlation was found between the activity of ethanolaminephosphate cytidylyltransferase and the rate of phosphatidylethanolamine synthesis. The present results indicate that the synthesis of triacylglycerols, phosphatidylcholines, and phosphatidylethanolamines is controlled by the availability of the various substrates as well as by the activities of several enzymes involved in these processes.
\end{abstract}

Although the pathways involved in the biosynthesis of hepatic glycerolipids have been largely elucidated almost two decades ago (1), our knowledge on the regulation of glycerolipid synthesis in the liver is still rudimentary. Evidence is accruing (2-6) that the activity of phosphatidate phosphatase (EC 3.1.3.4) which catalyzes the conversion of phosphatidic acid into diacylglycerols (DG), ${ }^{2}$ determines the flux of $D G$ to triacylglycerols (TG). However, DG are also utilized as direct precursors in the synthesis of phosphatidylcholines (PC) and

1 To whom all correspondence should be sent.

${ }^{2}$ Abbreviations used: DG, diacylglycerols; TG, triacylglycerols; PC, phosphatidylcholines; PE, phosphatidylethanolamines. phosphatidylethanolamines (PE). In view of the divergent functions of $\mathrm{TG}$ as energy source and those of $\mathrm{PC}$ and $\mathrm{PE}$ as essential membrane components, it is to be expected that the synthesis of $\mathrm{TG}$ and that of the two phospholipids are regulated independently. This view is supported by results from dietary studies. Experiments in vivo $(7,8)$ and in vitro with isolated rat hepatocytes (8) and rat liver slices (9) have demonstrated that the rates of synthesis of $\mathrm{TG}, \mathrm{PC}$, and $\mathrm{PE}$ in the liver respond differently to changes in the nutritional state of the rat. Fasting caused a strong inhibition of the synthesis of TG, whereas the formation of PC and, particularly, that of PE were much less affected (7-9). Refeeding of high-carbohy- 
drate, fat-free diets to fasted rats resulted in a drastic increase in the synthesis of TG in the liver both in vivo $(7,8,10)$ and in vitro (5, 7-9). The synthesis of PC was only slightly enhanced whereas the synthesis of $\mathrm{PE}$ was even further repressed $(7,8)$.

Experiments of Gibson and colleagues $(11,12)$ have shown that refeeding highcarbohydrate, fat-free diets to fasted rats causes rapid and drastic alterations in the fatty acid composition of the total lipids fraction and TG of the liver. It was thought of interest to investigate in the present study how fasting and fasting followed by refeeding influence the fatty acid profiles of TG, $\mathrm{PC}$, and $\mathrm{PE}$ in relation to the changes in DG, the common precursors of these glycerolipids.

In addition, it was investigated how the nutritional state affects the activities of various enzymes involved in the biosynthesis of TG, PC, and PE. This may provide further information on the question which enzyme(s) may be important in the regulation of the synthesis of these glycerolipids in the liver.

\section{MATERIALS AND METHODS}

Animals. Male Wistar rats, weighing 225-300 g, were obtained from the Central Institute for the Breeding of Laboratory Animals, Zeist, The Netherlands. Rats of three different nutritional states were used throughout this study: (a) rats fed ad libitum a regular chow pellet diet, (b) rats fasted for $48 \mathrm{~h}$, and (c) rats fasted for $48 \mathrm{~h}$ and subsequently refed $a d$ libitum a high-sucrose, fat-free diet for $24 \mathrm{~h}$. In some experiments the animals were refed for $72 \mathrm{~h}$. All animals had free access to water. The composition of the regular chow pellets and the high-sucrose, fat-free diet have been described in detail earlier (8).

Preparation of subcellular fractions. The rats were killed by decapitation. The livers were removed and homogenized in $0.33 \mathrm{M}$ sucrose/0.01 $\mathrm{M}$ Tris $(\mathrm{pH}$ 7.4) with the aid of a Potter-Elvehjem homogenizer $(1 \mathrm{~g}$ liver $/ 10 \mathrm{ml}$ ). The microsomal and $105,000 \mathrm{~g}$ supernatant fractions were isolated from the liver homogenates as described previously (13). The microsomal pellets were resuspended in $0.125 \mathrm{M} \mathrm{KCl} / 0.1 \mathrm{M}$ Tris $(\mathrm{pH} \mathrm{7.4)}$. Protein contents of the various subcellular fractions were estimated by the method of Lowry et al. (14).

Measurements of enzyme activities. Cholinephosphotransferase (EC 2.7.8.2) and ethanolaminephosphotransferase (EC 2.7.8.1) were assayed in the microsomal fractions using the endogenous $\mathrm{DG}$ as substrates. Microsomes (0.4-0.6 $\mathrm{mg}$ of protein) were incubated at $37^{\circ} \mathrm{C}$ in $0.5 \mathrm{ml}$ medium of the following composition: $20 \mathrm{mM}$ Tris- $\mathrm{HCl}(\mathrm{pH} 7.4), 0.2 \mathrm{mM}$ CDP- $\left[\right.$ methyl $\left.-{ }^{14} \mathrm{C}\right]-$ choline (sp act $0.25 \mathrm{Ci} / \mathrm{mol}$ ) or $0.2 \mathrm{mM} \mathrm{CDP}-\left[2{ }^{14} \mathrm{C}\right]$ ethanolamine (sp act $1.25 \mathrm{Ci} / \mathrm{mol}$ ), $10 \mathrm{mM} \mathrm{MgCl}$, and $4 \mathrm{mM}$ dithiothreitol. The formation of radioactive $\mathrm{PC}$ or PE was monitored by the filter disk method introduced by Goldfine (15). The filter disks were transferred into scintillation vials containing $5 \mathrm{ml}$ of a scintillation medium composed as described by Fricke (16). Quench corrections were made by the channels ratio method.

Diacylglycerol acyltransferase (EC 2.3.1.20) was also assayed in the microsomal fraction using endogenous diacylglycerols as substrates. Microsomes (0.4$0.6 \mathrm{mg}$ of protein) were incubated at $37^{\circ} \mathrm{C}$ in a medium which contained the following components: $80 \mathrm{mM}$ Tris- $\mathrm{HCl}(\mathrm{pH} 7.4), 10 \mathrm{mM} \mathrm{MgCl}_{2}, 4 \mathrm{mM}$ dithiothreitol, and $0.1 \mathrm{mM}\left[1{ }^{14} \mathrm{C}\right]$ palmitoyl-CoA (sp aet $1.0 \mathrm{Ci} / \mathrm{mol}$ ) in a total volume of $0.5 \mathrm{ml}$. The reactions were terminated after $0.5,1,1.5$, and $2 \mathrm{~min}$ by the addition of $2 \mathrm{ml}$ methanol-chloroform (2:1, v/v). After extraction of the lipids (17), the TG were isolated via thin-layer chromatography (see below) and assayed for radioactivity.

Phosphatidate phosphatase was measured in the $105,000 \mathrm{~g}$ supernatant fractions exactly as described by Mangiapane $e t a l$. (3). Mierosomal-bound $\left[{ }^{14} \mathrm{C}\right]$ phosphatidate, prepared as reported by Lamb and Fallon (18), was used as substrate. Choline kinase (EC 2.7. 1.32) and ethanolamine kinase were determined in the $105,000 \mathrm{~g}$ cytosol fraction according to the method reported by Weinhold and Rethy (19).

Cholinephosphate cytidylyltransferase (EC 2.7.7.15) and ethanolaminephosphate cytidylyltransferase (EC 2.7.7.14) were assayed in the $105,000 \mathrm{~g}$ fractions as described in detail by Sundler (20).

Analysis of lipids. DG and TG were isolated by thin-layer chromatography on silica gel $G$ using petroleum ether (bp $40-60^{\circ} \mathrm{C}$ ):diethylether:acetic acid (80:20:2, $\mathrm{v} / \mathrm{v})$ as developing solvent and recovered from the silica by extraction with diethylether. Phospholipids were separated via two-dimensional thin-layer chromatography as described by Broekhuyse (21). PC and PE were extracted from the silica by the method of Bligh and Dyer (17) and that of Arvidson (22), respectively. The fatty acid composition of the various lipids was determined as reported earlier (23). The amounts of $\mathrm{DG}$ and $\mathrm{TG}$ were determined by adding heptadecanoic acid as an internal standard during the gas chromatographic analysis of the fatty acyl constituents of these lipids (23). Quantitation of PC and PE was accomplished by phosphorus analysis (24).

Radioactive compounds. $\left[1{ }^{11} \mathrm{C}\right] \mathrm{Palmitic}$ acid (sp act $56 \mathrm{Ci} / \mathrm{mol}$ ) and $\left[1-{ }^{14} \mathrm{C}\right]$ palmitoyl-CoA (sp act $54.8 \mathrm{Ci} / \mathrm{mol}$ ) were obtained from the Radiochemical Centre, Amersham, U. K. [methyl- $\left.{ }^{14} \mathrm{C}\right]$ Choline chloride (sp act 52 $\mathrm{Ci} / \mathrm{mol}$ ), $\left[1,2-{ }^{14} \mathrm{C}_{2}\right]$ ethanolamine (sp act $55 \mathrm{Ci} / \mathrm{mol}$ ), [methyl $\left.{ }^{14} \mathrm{C}\right]$ cholinephosphate (sp act $\left.52 \mathrm{Ci} / \mathrm{mol}\right),[1,2$ ${ }^{14} \mathrm{C}_{2}$ ]ethanolaminephosphate (sp act $225 \mathrm{Ci} / \mathrm{mol}$ ), CDP- 
TABLE I

Fatty Acid Composition (\%) and Amounts of Diacylglycerols, Triacylglycerols, Phosphatidylcholines, and Phosphatidylethanolamines of the LIVERS OF RATS OF DIFFERENT NUTRITIONAL STATES ${ }^{a}$

\begin{tabular}{|c|c|c|c|c|c|c|c|c|}
\hline & $\begin{array}{l}\text { Normally } \\
\text { fed }\end{array}$ & $48 \mathrm{~h}$ fasted & $\begin{array}{l}48 \text { h fasted, } \\
24 \text { h refed }\end{array}$ & $\begin{array}{l}48 \text { h fasted, } \\
72 \text { h refed }\end{array}$ & $\begin{array}{l}\text { Normally } \\
\text { fed }\end{array}$ & $48 \mathrm{~h}$ fasted & $\begin{array}{l}48 \text { h fasted, } \\
24 \text { h refed }\end{array}$ & $\begin{array}{l}48 \text { h fasted, } \\
72 \mathrm{~h} \text { refed }\end{array}$ \\
\hline & \multicolumn{4}{|c|}{ Diacylglycerols } & \multicolumn{4}{|c|}{ Triacylglycerols } \\
\hline Amounts & $21.3 \pm 5.5$ & $5.7 \pm 0.6^{b}$ & $15.0 \pm 2.7^{r}$ & $80.0 \pm 12.8^{c}$ & $70.7 \pm 5.5$ & $23.7 \pm 5.5^{b}$ & $83.0 \pm 12.5$ & $1024 \pm 229$ \\
\hline \multirow{9}{*}{$\begin{array}{r}\text { Fatty acids } 16: 0 \\
16: 1 \\
18: 0\end{array}$} & $38.6 \pm 2.1$ & $36.4 \pm 2.8$ & $31.2 \pm 3.0$ & $44.4 \pm 0.8^{c}$ & $27.5 \pm 1.4$ & $33.5 \pm 4.6$ & $31.7 \pm 2.0$ & $42.8 \pm 0.7^{c}$ \\
\hline & & & $15.3 \pm 2.6^{c}$ & $11.1 \pm 0.8^{r}$ & $4.2 \pm 1.9$ & $4.2 \pm 0.2$ & $13.9 \pm 2.0^{r}$ & $14.6 \pm 0.7^{r}$ \\
\hline & $18.0 \pm 1.7$ & $22.1 \pm 1.6$ & $6.4 \pm 1.5^{r}$ & $2.8 \pm 1.6^{c}$ & $4.5 \pm 1.1$ & $6.8 \pm 2.8$ & $4.6 \pm 1.5$ & $0.2 \pm 0.1^{r}$ \\
\hline & $15.6 \pm 0.6$ & $11.7 \pm 0.2^{b}$ & $36.1 \pm 1.9^{c}$ & $41.6 \pm 1.0^{c}$ & $28.9 \pm 1.1$ & $27.2 \pm 5.1$ & $39.4 \pm 3.2^{c}$ & $42.4 \pm 0.4^{c}$ \\
\hline & $18.7 \pm 1.3$ & $14.8 \pm 0.3^{b}$ & $7.3 \pm 1.7^{c}$ & & $34.9 \pm 2.8$ & $28.3 \pm 0.8^{b}$ & $10.6 \pm 3.0^{c}$ & \\
\hline & & & & & & & & \\
\hline & $9.0 \pm 2.5$ & $15.0 \pm 0.1^{b}$ & $3.6 \pm 3.2^{r}$ & & $\operatorname{tr}$ & $\operatorname{tr}$ & $\operatorname{tr}$ & \\
\hline & & & & & & & & \\
\hline & \multicolumn{4}{|c|}{ Phosphatidylcholines } & \multicolumn{4}{|c|}{ Phosphatidylethanolamines } \\
\hline Amounts & $161 \pm 15.4$ & $97.9 \pm 7.6^{b}$ & $122 \pm 13.0$ & $183.7 \pm 12.6^{r}$ & $72.5 \pm 3.3$ & $61.5 \pm 2.1^{b}$ & $49.7 \pm 3.1^{r}$ & $58.4 \pm 6.9$ \\
\hline \multirow{8}{*}{ Fatty acids } & $26.2 \pm 2.2$ & $29.8 \pm 1.4$ & $33.2 \pm 1.9$ & $28.6 \pm 2.8$ & $21.0 \pm 2.9$ & $19.3 \pm 0.6$ & $25.4 \pm 0.4$ & $25.4 \pm 0.3^{r}$ \\
\hline & & & $7.6 \pm 0.8^{c}$ & $7.1 \pm 0.6^{r}$ & & & $\operatorname{tr}$ & $2.6 \pm 0.4^{r}$ \\
\hline & $22.0 \pm 1.7$ & $22.2 \pm 1.7$ & $14.5 \pm 1.6^{c}$ & $17.2 \pm 0.6^{r}$ & $23.0 \pm 0.7$ & $26.9 \pm 0.9^{b}$ & $21.6 \pm 0.6^{r}$ & $19.6 \pm 0.1^{c}$ \\
\hline & $9.3 \pm 1.0$ & $7.5 \pm 0.5$ & $19.0 \pm 0.9 r$ & $27.2 \pm 1.8^{r}$ & $7.4 \pm 1.6$ & $4.3 \pm 0.9$ & $9.5 \pm 1.3 r$ & $15.2 \pm 0.8^{c}$ \\
\hline & $18.8 \pm 1.3$ & $13.9 \pm 0.1^{b}$ & $8.3 \pm 0.6^{c}$ & $3.0 \pm 0.1^{c}$ & $9.3 \pm 1.3$ & $6.1 \pm 1.2$ & $4.3 \pm 0.6$ & $1.0 \pm 0.3^{r}$ \\
\hline & & & & $7.6 \pm 0.3^{r}$ & & & & $2.4 \pm 0.6^{c}$ \\
\hline & $23.6 \pm 1.9$ & $26.5 \pm 0.7^{b}$ & $17.3 \pm 1.1^{c}$ & $9.1 \pm 0.9$ & $24.7 \pm 1.9$ & $25.5 \pm 1.7$ & $24.2 \pm 1.6$ & $25.8 \pm 2.0$ \\
\hline & tr & $\operatorname{tr}$ & $\operatorname{tr}$ & $\operatorname{tr}$ & $14.5 \pm 2.3$ & $18.0 \pm 3.3$ & $15.0 \pm 2.7$ & $7.8 \pm 0.4^{e}$ \\
\hline
\end{tabular}

"Means \pm S.D. of three rats are presented. The amounts of the various lipids are given as $\mu \mathrm{mol} / \mathrm{liver}$

${ }^{b}$ Significantly different from normally fed rats $(P<0.01)$.

- Signiflcantly different from 48 -h fasted rats $(P<0.01)$.

[methyl- $\left.{ }^{14} \mathrm{C}\right] \mathrm{choline}(\mathrm{sp}$ act $40 \mathrm{Ci} / \mathrm{mol})$, and CDP-[2-14 $\left.\mathrm{C}\right]-$ ethanolamine (sp act $28 \mathrm{Ci} / \mathrm{mol}$ ) were purchased from NEN-Chemicals, Dreieichenhain, FRG.

\section{RESULTS}

The Influence of Fasting and Refeeding on the Fatty Acid Composition of DG, TG, $P C$, and $P E$

Table I presents the fatty acid composition of DG, TG, PC, and PE of the liver of rats kept in various nutritional states. Fasting did not cause pronounced alterations in the fatty acid composition of these glycerolipids, which is in agreement with reports by other investigators $(11,12,22)$. Refeeding a high-sucrose, fat-free diet to $48-h$ fasted rats profoundly changed the fatty acid profile of hepatic DG within $24 \mathrm{~h}$ : Strong increases occurred in the proportions of palmitoleic (16:1) and oleic acids (18:1). These increases were compensated by considerable reductions in the contents of stearic (18:0), arachidonic (20:4), and linoleic acids (18:2). The effects of the refeeding on the composition of DG were even more pronounced after refeeding for $72 \mathrm{~h}$. The changes in the fatty acid profile of $\mathrm{DG}$ were reflected by similar changes in the composition of TG and PC. The decrease of arachidonic acid in $\mathrm{PC}$ seems, however, less pronounced than that in DG. Moreover, the appearance of eicosatrienoic acid (20:3), not detected in DG, seemed to partly compensate for the decreased level of arachidonic acid in PC. Apparently, eicosatrienoic acid is introduced into $\mathrm{PC}$ by a deacylation-reacylation process (25) rather than via synthesis de novo. The fatty acid composition of $\mathrm{PE}$ was much less affected by the refeeding despite the drastic alterations in DG, the direct precursor in the de novo synthesis of PE. Even after refeeding for $72 \mathrm{~h}$, the content of arachidonic acid of $\mathrm{PE}$ was not reduced. Also, the increase in the proportion of palmitoleic acid in $\mathrm{PE}$ was minor despite the abundance of this fatty acid in DG. Gibson and colleagues $(11,12)$ have reported similar increases in the proportions of oleic and palmitoleic acid and decreases in linoleic and arachidonic acid in total lipids and TG of rat liver upon refeeding of fasted rats. However, these au- 
TABLE II

Cytosolic Phosphatidate Phosphatase ACtivity in the Livers OF RATS OF DIFFERENT NUTRITIONAL STATES ${ }^{a}$

\begin{tabular}{lcc}
\hline \multicolumn{1}{c}{ Nutritional state } & $\begin{array}{c}\text { Specific activity } \\
\text { (nmol/min/mg protein) }\end{array}$ & $\begin{array}{c}\text { Total activity } \\
\text { (nmol/min per liver) }\end{array}$ \\
\hline $\begin{array}{l}\text { Normally fed } \\
\text { 48-h fasted }\end{array}$ & $1.85 \pm 0.48$ & $1009 \pm 321$ \\
$\begin{array}{l}\text { 48-h fasted and 24-h refed } \\
\text { a high-sucrose, fat-free } \\
\text { diet }\end{array}$ & $2.55 \pm 0.18$ & $1123 \pm 116$ \\
\hline
\end{tabular}

${ }^{a}$ Incubations were performed in the presence of $178 \mathrm{nmol}$ microsome-bound phosphatidic acid $(92 \mathrm{nmol} / \mathrm{mg}$ microsomal protein). For further experimental details see Materials and Methods. Means \pm SD of three rats are presented.

${ }^{b}$ Significantly different from normally fed and 48-h fasted rats $(P<0.01)$.

thors did not investigate the different effects of the refeeding on the composition of $\mathrm{PC}$ and $\mathrm{PF}$ nor the alterations in DG, the common precursors of TG, PC, and PE.

As reported earlier (8), the dietary state also affects the amounts of various lipid classes in the liver. Fasting strongly reduces the levels of DG and TG whereas the amounts of $\mathrm{PC}$ and, particularly, $\mathrm{PE}$ are much less affected. Refeeding for $24 \mathrm{~h}$ results in significant increases in the contents of $D G$ and TG which are even more pronounced after refeeding for $72 \mathrm{~h}$. Particularly interesting is the observation that refeeding for $72 \mathrm{~h}$ hardly affects the level of PE. (Table I)

\section{The Influence of Fasting and Refeeding}

on the Activities of Enzymes Involved

in the Formation of TG, PC, and PE.

Phosphatidate phosphatase. The conversion of phosphatidic acid into DG is a common step in the synthesis of TG, PC, and $\mathrm{PE}$. Although phosphatidate phosphatase is also present in liver microsomes, several authors have concluded that the $105,000 \mathrm{~g}$ supernatant is the major source of this enzyme in the liver $(18,26)$. Table II shows the changes measured in the specific and total activities of the soluble phosphatidate phosphatase after fasting and fasting followed by refeeding. It was found that refeeding of fasted rats resulted in a drastic increase in both the specific and total activity of the enzyme. This increase may be responsible for the strongly enhanced forma- tion of TG measured in this dietary condition $(7,8,10)$. Although fasting for $48 \mathrm{~h}$ caused a slight increase in the specific activity of phosphatidate phosphatase, the total activity did not differ from the value measured in the control rats. This is in contrast with the results of Vavrečka et al. (2) who reported an increased activity of this enzyme in the liver of fasted rats. Their observation, however, cannot easily explain the strong decrease in the formation of $\mathrm{TG}$ in the fasted state reported by most investigators $(7-9,27,28)$.

Diacylglycerol acyltransferase, cholinephosphotransferase, and ethanolaminephosphotransferase. The effects of fasting and refeeding on the specific and total activities of these three enzymes, which catalyze the conversions of $\mathrm{DG}$ into $\mathrm{TG}, \mathrm{PC}$, and $\mathrm{PE}$, respectively, are shown in Table III. These enzymes are localized in the microsomal fraction of the liver $(29,30)$ and were measured using endogenous DG as substrates. Fasting did not influence the specific activities of diacylglycerol acyltransferase, cholinephosphotransferase, or ethanolaminephosphotransferase. However, the total activities of these three enzymes were decreased in microsomes from fasted rats when compared to microsomes from normally fed animals. Refeeding a high-sucrose, fat-free diet did restore the total activity of cholinephosphotransferase to that measured in microsomes from control rats. The same phenomenon, although less pronounced, was observed for diacylglycerol acyltrans- 
TABLE III

ACtivities of DiaCYLGLYCEROL ACYLTRANSFERASE, ChOLINEPHOSPHOTRANSFERASE, AND ETHANOLAMINEPHOSPHOTRANSFERASE IN THE LIVERS OF RATS OF DIFFERENT NUTRITIONAL STATES ${ }^{a}$

\begin{tabular}{|c|c|c|c|c|c|c|}
\hline \multirow[b]{2}{*}{ Nutritional state } & \multicolumn{3}{|c|}{$\begin{array}{c}\text { Specific activity } \\
\text { (nmol/min/mg protein) }\end{array}$} & \multicolumn{3}{|c|}{$\begin{array}{c}\text { Total activity } \\
\text { (nmol/min per liver) }\end{array}$} \\
\hline & DGAT $^{b}$ & CPT & EPT & DGAT & $\mathrm{CPT}$ & $\mathrm{EPT}$ \\
\hline Normally fed & $1.9 \pm 0.2$ & $1.0 \pm 0.2$ & $0.09 \pm 0.03$ & $576 \pm 61$ & $303 \pm 61$ & $27 \pm 9$ \\
\hline 48-h fasted & $1.8 \pm 0.1$ & $1.1 \pm 0.2$ & $0.12 \pm 0.03$ & $241 \pm 13^{c}$ & $147 \pm 27^{c}$ & $16 \pm 4$ \\
\hline $\begin{array}{l}\text { 48-h fasted and } 24 \text {-h refed } \\
\text { a high-sucrose, fat-free } \\
\text { diet }\end{array}$ & $2.5 \pm 0.2^{d}$ & $2.4 \pm 0.1^{d}$ & $0.11 \pm 0.04$ & $384 \pm 31^{d}$ & $368 \pm 15^{d}$ & $17 \pm 6$ \\
\hline
\end{tabular}

a Means \pm SD of three rats are presented. Incubations were carried out as described under Materials and Methods.

'Abbreviations used: DGAT, diacylglycerolacyltransferase; CPT, cholinephosphotransferase; EPT, ethanolaminephosphotransferase.

c Significantly different from normally fed rats $(P<0.01)$.

${ }^{a}$ Significantly different from 48 -h fasted rats and normally fed rats $(P<0.01)$.

ferase. Interestingly, the activity of ethanolaminephosphotransferase was not increased upon refeeding.

It should be realized that the content of DG in liver microsomes varies with the nutritional state (Table IV): It is decreased in the liver of the fasted rats and increased in the refed state. However, it is unlikely that the increased specific activities of diacylglycerol acyltransferase and cholinephosphotransferase in microsomes from refed rats are due to the increased availability of DG since fasting did not affect the specific activities of these enzymes notwithstanding the large decrease in the level of endogenous DG.

Enzymes involved in the synthesis of $C D P$-choline and CDP-ethanolamine. CDPcholine is synthesized from choline and CTP by the sequential action of choline kinase and cholinephosphate cytidylyltransferase. The specific and total activities of choline kinase were decreased significantly by fasting. These decreases were not reversed by refeeding a high-sucrose, fat-free diet for $24 \mathrm{~h}$. (Table V). Fasting resulted also in a diminished activity of cholinephosphate cytidylyltransferase. The activity of this enzyme was, however, restored by refeeding to the value measured in normally fed rats.

The activities of ethanolamine kinase and ethanolaminephosphate cytidylyltransferase which catalyze the formation of ethanolaminephosphate and CDP-ethanolamine, respectively, were also measured in the $105,000 \mathrm{~g}$ supernatant fractions. Fasting strongly depressed both the specific and total activities of ethanolamine kinase. These decreases were partly reversed by refeeding for $24 \mathrm{~h}$. The activity of ethanolaminephosphate cytidylyltransferase was

\section{TABLE IV}

LeVels of DiacylgLycerols in Microsomes From THE LIVERS OF RatS OF DIFFERENT NUTRITIONAL STATES ${ }^{a}$

\begin{tabular}{|c|c|c|}
\hline \multirow[b]{2}{*}{ Nutritional state } & \multicolumn{2}{|c|}{ Diacylglycerols } \\
\hline & $\begin{array}{c}\mathrm{nmol} / \mathrm{mg} \\
\text { protein }\end{array}$ & $\begin{array}{l}\text { Total amount } \\
\text { (nmol) }\end{array}$ \\
\hline $\begin{array}{l}\text { Normally fed } \\
\text { 48-h fasted } \\
\text { 48-h fasted and } 24-h \text { refed } \\
\text { a high-sucrose, fat-free } \\
\text { diet }\end{array}$ & $\begin{array}{r}11.8 \pm 3.5 \\
4.2 \pm 1.0^{b}\end{array}$ & $\begin{aligned} 3577 & \pm 1061 \\
562 & \pm 133^{b} \\
2457 & \pm 430^{c}\end{aligned}$ \\
\hline $\begin{array}{l}{ }^{a} \text { Means } \pm \text { SD of three } \\
{ }^{b} \text { Significantly different } \\
(P<0.01) . \\
{ }^{c} \text { Significantly different } \\
<0.01) .\end{array}$ & $\begin{array}{l}\text { rats are pres } \\
\text { from norm } \\
\text { from } 48-h \text { f }\end{array}$ & $\begin{array}{l}\text { ented. } \\
\text { nally fed rats } \\
\text { asted rats ( } P\end{array}$ \\
\hline
\end{tabular}


TABLE V

ACTivities of Choline Kinase and ChOLINEPHosphate Cytidylyltransferase in Liver SUPERNATANTS OF RATS OF DifFERENT NUTRITIONAL STATES ${ }^{a}$

\begin{tabular}{|c|c|c|c|c|}
\hline \multirow[b]{2}{*}{ Nutritional state } & \multicolumn{2}{|c|}{$\begin{array}{c}\text { Specific activity } \\
\text { (nmol/min per mg protein) }\end{array}$} & \multicolumn{2}{|c|}{$\begin{array}{c}\text { Total activity } \\
\text { (nmol/min per liver) }\end{array}$} \\
\hline & $\begin{array}{l}\text { Choline } \\
\text { kinase }\end{array}$ & $\begin{array}{l}\text { Cholinephosphate } \\
\text { cytidylyltransferase }\end{array}$ & $\begin{array}{l}\text { Choline } \\
\text { kinase }\end{array}$ & $\begin{array}{l}\text { Cholinephosphate } \\
\text { cytidylyltransferase }\end{array}$ \\
\hline Normally fed & $1.28 \pm 0.23$ & $0.38 \pm 0.07$ & $722 \pm 80$ & $214 \pm 22$ \\
\hline 48-h fasted & $0.64 \pm 0.07^{b}$ & $0.31 \pm 0.06$ & $316 \pm 32^{b}$ & $151 \pm 18^{b}$ \\
\hline $\begin{array}{l}\text { 48-h fasted and 24-h refed } \\
\text { a high-sucrose, fat-free } \\
\text { diet }\end{array}$ & $0.39 \pm 0.06^{c}$ & $0.35 \pm 0.11$ & $256 \pm 56$ & $235 \pm 86$ \\
\hline
\end{tabular}

${ }^{a}$ Means \pm SD of three rats are presented. Incubations were carried out as described under Materials and Methods.

${ }^{b}$ Significantly different from normally fed rats $(P<0.01)$.

c Significantly different from fasted rats $(P<0.01)$.

also decreased by fasting and, subsequently, increased by refeeding.

\section{DISCUSSION}

'The nutritional state of the rat undoubtedly plays a major role in the partitioning of DG among TG, PC, and PE. It was shown recently $(8,9)$ that the synthesis of TG and that of $\mathrm{PC}$ and $\mathrm{PE}$ responded differently to changes in the dietary state. Particularly important in this respect was the finding that refeeding fasted rats for $24 \mathrm{~h}$ resulted in a strongly enhanced synthesis of TG whereas the formation of $\mathrm{PC}$ was only slightly enhanced and that of PE even further depressed. Even after continued refeeding for $72 \mathrm{~h}$ the level of PE is still lower than that in normally fed rats despite the accumulation of DG (Table I). It seems that the level of DG is not important in determining the rate of synthesis of $\mathrm{PC}$ and $\mathrm{PE}$ in vivo. It should be noted, however, that the composition of DG is drastically altered after refeeding for 24 or $72 \mathrm{~h}$ (Table I). Particularly, the degree of unsaturation is severely depressed. The changes in DG are reflected by analogous alterations in the fatty acid profiles of TG and, to some extent, of PC. Interestingly, the fatty acid composition of $\mathrm{PE}$ is hardly changed after refeeding. Apparently, the available molecular classes of DG are not suitable as substrates for the synthesis of PC and, particularly, PE. These findings extend an earlier suggestion by Sundler and Åkesson (31) that the fatty acid composition of the available DG may be an important factor in controlling the rate of synthesis of $\mathrm{PC}$ and $\mathrm{PE}$. In line with this concept is the recent report by Glenny et al. (32) that feeding an unsaturated corn-oil diet to rats resulted in an increased activity of cholinephosphotransferase in the liver.

The purpose of the present investigation was also to study the relation between the influence of the nutritional state on hepatic glycerolipid metabolism in vivo and the changes in the activities in vitro of a number of enzymes involved in these processes. Glycerolphosphate acyltransferase which catalyzes the step where fatty acids first become committed to glycerolipid synthesis, was not included in the present study since several investigators have studied the effect of fasting and refeeding on the activity of this enzyme $(3,33,34)$.

Of the enzymes involved in the formation of TG it is usually phosphatidate phosphatase in the soluble fraction which responds the most rapidly and to the greatest extent to various environmental changes $(5,6,34)$. As shown in Table II, the total activity of this enzyme is increased fourfold after refeeding a high-sucrose, fat-free diet to fasted rats. This finding, which supports earlier observations by Lamb and Fallon (4), could 
TABLE VI

ACtivities of Ethanolamine Kinase aNd Ethanolaminephosphate Cytidylyltransferase IN Liver Supernatants OF RATS OF Different NUtritional States ${ }^{a}$

\begin{tabular}{|c|c|c|c|c|}
\hline \multirow[b]{2}{*}{$\begin{array}{l}\text { Nutritional } \\
\text { state }\end{array}$} & \multicolumn{2}{|c|}{$\begin{array}{c}\text { Specific activity } \\
\text { (nmol/min per mg protein) }\end{array}$} & \multicolumn{2}{|c|}{$\begin{array}{c}\text { Total activity } \\
\text { (nmol/min per liver) }\end{array}$} \\
\hline & $\begin{array}{l}\text { Ethanolamine } \\
\text { kinase }\end{array}$ & $\begin{array}{c}\text { Ethanolaminephosphate } \\
\text { cytidylyltransferase }\end{array}$ & $\begin{array}{l}\text { Ethanolamine } \\
\text { kinase }\end{array}$ & $\begin{array}{c}\text { Ethanolaminephosphate } \\
\text { cytidylyltransferase }\end{array}$ \\
\hline Normally fed & $0.44 \pm 0.09$ & $2.31 \pm 0.22$ & $250 \pm 49$ & $1203 \pm 135$ \\
\hline 48-h fasted & $0.09 \pm 0.01^{b}$ & $1.85 \pm 0.03^{b}$ & $44 \pm 5^{b}$ & $879 \pm 20^{b}$ \\
\hline $\begin{array}{l}\text { 48-h fasted and } 24 \text {-h refed } \\
\text { a high-sucrose, fat-free } \\
\text { diet }\end{array}$ & $0.17 \pm 0.06$ & $2.76 \pm 0.33^{c}$ & $118 \pm 43^{c}$ & $1529 \pm 110^{c}$ \\
\hline
\end{tabular}

${ }^{a}$ Means $\pm \mathrm{SD}$ of three rats are presented. Incubations were carried out as described under Materials and Methods.

${ }^{b}$ Significantly different from normally fed rats $(P<0.01)$.

c Significantly different from fasted rats $(P<0.01)$.

explain the increased $\mathrm{TG}$ synthesis observed in refed rats. There is evidence that the activity of phosphatidate phosphatase is rate limiting in the synthesis of TG, at least in vitro $(4,35-38)$. The evidence for a regulatory function of this enzyme in vivo is still less convincing $(39,40)$. In this respect it is interesting to mention the accumulation of diacylglycerols in the liver of refed rats (Table I). In the present study, no alteration was found in the activity of phosphatidate phosphatase after fasting despite the fact that the synthesis and level of TG were severely depressed in this dietary state (7-9). However, the studies of McGarry et al. (28) indicate that fasting produces no defect in the ability to form TG in rat liver but diverts fatty acid substrates to ketogenesis. Therefore, the overall control of TG synthesis may be exerted both by the activity of the enzymatic pathway as well as by the flow of substrates.

The different effects of dietary alterations (7-9) or several hormones (41-43) on the synthesis of TG, PC, and PE suggest that the synthesis of these glycerolipids is not only regulated at a step prior to the formation of phosphatidic acid (44) or at the level of phosphatidate phosphatase $(5,6,34)$ but also at a step after the DG branchpoint. The alterations in the activities of diacylglycerol acyltransferase, cholinephosphotransferase, and ethanolaminephosphotransferase due to fasting and refeeding correlated well with the changes in the synthesis of TG, PC, and $\mathrm{PE}$ observed in vivo $(7,8)$, although the changes in diacylglycerol acyltransferase seem too moderate to account for the pronounced alterations of TG synthesis in vivo.

The results so far do suggest that the synthesis of $\mathrm{PC}$ and $\mathrm{PE}$ are regulated independently from that of $\mathrm{TG}$ and that any excess of DG, which may occur e.g., during refeeding, is channeled into TG. This view agrees with that of other investigators (31, 45 ) and is consistent with the fact that the content of $T G$ in the liver varies much more than the concentration of $\mathrm{PC}$ and $\mathrm{PE}$.

Less certainty exists on the question which factors regulate the distribution of DG between PC and PE. On the basis of theoretical principles of metabolic regulation, Infante recently concluded that cholineand ethanolaminephosphotransferase are not rate-limiting enzymes in the synthesis of PC and PE (46). From the data presented in Table III a role of these enzymes in the regulation of $\mathrm{PC}$ and $\mathrm{PE}$ synthesis can, nevertheless, not be excluded. It is possible that the different affinities of these enzymes toward a given class of DG may determine whether a particular DG is utilized for the synthesis of $\mathrm{PC}$ or that of PE. Another possibility is that the concentrations of CDPcholine and CDP-ethanolamine affect the activities of choline- and ethanolaminephos- 
photransferase (31). In the sequence of enzymes which catalyze the formation of CDPcholine, cholinephosphate cytidylyltransferase has the lowest activity if the enzymes are measured in vitro under optimal conditions. The alterations in the activity of this enzyme due to changes in the nutritional state (Table $V$ ) run parallel with the changes observed in the synthesis of PC in vivo $(7,8)$. This supports the concept that cholinephosphate cytidylyltransferase might be rate limiting in the formation of CDP-choline and, possibly, that of PC $(31,47)$. In the synthesis of CDP-ethanolamine the lowest activity was measured for ethanolamine kinase which is in agreement with the results of Schneider and Vance (47). The alterations in the activities of ethanolamine kinase and ethanolaminephosphate cytidylyltransferase due to fasting and fasting followed by refeeding do not correlate with the changes observed for the synthesis of $\mathrm{PE}$ in vivo. The increased activities of these enzymes after refeeding (Table VI) are not expressed in increased levels of PE. This may indicate that the changes in the fatty acid composition of DG after refeeding (Table I) exert a larger influence on the formation of PE than changes in the supply of CDPethanolamine.

As a conclusion it may be suggested that the distribution of DG among TG, PC, and $\mathrm{PE}$ is under multiple control. Probably the synthesis of TG serves predominantly as an overflow mechanism for those DG which are not utilized for conversion into $\mathrm{PC}$ and $\mathrm{PE}$. The synthesis of these phospholipids appears to be controlled by the availability of the various substrates as well as by the activities of several enzymes involved in these processes.

\section{ACKNOWLEDGMENTS}

The investigations were supported in part by the Netherlands Foundation for Chemical Research (SON) with financial aid from the Netherlands Organization for the Advancement of Pure Research (ZWO).

\section{REFERENCES}

1. Kennedy, E. P. (1961) Fed. Proc. 20, 934-940.

2. VaVRecka, M., Mitchell, M. P., aNd HưbSCHER, G. (1969) Biochetr. J. 115, 139-145.
3. Mangiapane, E. H., Lloyd-Davies, K. A., AND BRINDLEY, D. N. (1973) Biochem. J. 134, 103-112.

4. LAMB, R. G., AND FalloN, H. J. (1974) Biochim. Biophys, Acta 348, 179-188.

5. Fallon, H. J., Lamb, R. G., and Jamdar, S. C. (1977) Biochem. Soc. Trans. 5, 37-40.

6. BRINDLEY, D. N. (1978) Int. J. Obesity 2, 7-16.

7. Park, C. E., Marai, E., and MookerJea, S. (1972) Biochim. Biophys. Acta 270, 50-59.

8. Groener, J. E. M., ANd van Golde, L. M. G. (1977) Biochim. Biophys. Acta 487, 105-114.

9. Iritani, N., Yamashita, S., AND Numa, S. (1976) J. Biochem. 80, 217-222.

10. Waddell, M., and Fallon, H. J. (1973) J. Clin. Invest. 52, 2725-2731.

11. Allmann, D. W., ANd Gibson, D. M. (1965) $J$. Lipid Res. 6, 51-62.

12. AllmanN, D. W., Hubbard, D. D., AND Gibson, D. M. (1965) J. Lipid Res. 6, 63-74.

13. Vereyken, J. M., MonTfoort, A., AND VAN GoLdE, L. M. G. (1972) Biochim. Biophys. Acta 260, $70-81$.

14. Lowry, O. H., Rosebrough, N. J., FARR, A. L., AND Randall, R. J. (1951) J. Biol. Chem. $193,265-275$.

15. Goldfine, H. (1966) J. Lipid Res. 7, 146-149.

16. FrICKe, U. (1975) Anal. Riochem. 63, 555-558.

17. Bligh, E. G., AND Dyer, W. J. (1959) Canad. J. Biochem. Physiol. 37, 911-917.

18. LAMB, R. G., AND Fallon, H. J. (1974) Biochim. Biophys. Acta. 348, 166-178.

19. Weinhold, P. A., AND RETHY, V. B. (1974) Biochemistry 13, 5135-5141.

20. Sundler, R. (1975) J. Biol. Chem. 250, 85858590 .

21. BRoekhuYse, R. M. (1969) Clin. Chim. Acta 23, $457-463$.

22. ARvidson, G. A. E. (1968) Eur. J. Biochem. 4, $478-486$.

23. Van Golde, L. M. G., AND van Deenen, L. L. M. (1966) Biochim. Biophys. Acta 125, 496-509.

24. Bartlett, G. R. (1959) J. Biol. Chem. 234, 466468.

25. LANDS, W. E. M. (1960) J. Biol. Chem. 235, 22332237.

26. Mitchell, M. P., Brindley, D. N., and HÜbSCHER, G. (1971) Eur. J. Biochem. 18, 214-220.

27. FAllon, H. J., AND KEMP, E. L. (1968) J. Clin. Invest. 47, 712-719.

28. McGarry, J. D., Meier, J. M., AND Foster, D. W. (1973) J. Biol. Chem. 248, 270-278.

29. Wilgram, G. F., ANd KenNedy, E. P. (1963) J. Biol. Chem. 238, 2615-2619.

30. VAN Golde, L. M. G., Fleischer, B., aND Fleischer, S. (1971) Biochim. Biophys. Acta 249, 318-330. 
31. SundleR, R., ANd Åkesson, B. (1975) J. Biol. Chem. 250, 3359-3367.

32. Glenny, H. P., Bowley, M., BurditT, S. L., Cooling, J., Pritchard, P. H., Sturton, R. G., AND BRINDLEY, D. N. (1978) Biochem. $J$. 174, 535-541.

33. Aas, M., anD DAAE, L. N. W. (1971) Biochim. Biophys. Acta 239, 208-216.

34. BRINDLEY, D. N. (1978) in Regulation of Fatty Acid and Glycerolipid Metabolism (Dils, R., and Knudsen, J., eds.), pp. 31-40, Pergamon, Oxford/New York.

35. HÚbSCher, G., Brindley, D. N., Smith, M. E., AND SEDGWICK, B. (1967) Nature (London) 216, $449-453$.

36. BRINDLEY, D. N., AND BOWLEY, M. (1975) Biochem. J. 148, 461-469.

37. BRindley, D. N., Bowley, M., Sturton, R. G., PRITChaRd, P. H., BurditT, S. L., AND Cooling, J. (1977) Biochem. Soc. Trans. 5, $40-43$.

38. Sturton, R. G., ANd Brindley, D. N. (1977) Biochem. J. 162, 25-32.
39. Brindley, D. N., Bowley, M., BurditT, S., HAYDN PRITCHARD, P., LLOYD-DAVIES, K. A., AND Boucrot, P. (1976) J. Pharm. Pharmacol. 28, 676-682.

40. BRindley, D. N., Bowley, M., StuRton, R. G., HAYdN PRITChaRd, P., BurditT, S. L., AND Cooling, J. (1978) in Central Mechanisms of Anorectic Drugs (Garattini, S., and Samanin, R., ed.), pp. 301-317, Raven Press, New York.

41. Young, D. L., AND Lynen, F. (1969) J. Biol. Chem. 244, 377-383.

42. Coleman, R., Polokoff, M. A., AND Bell, R. M. (1977) Metabolism 26, 1123-1130.

43. Geelen, M. J. H., Groener, J. E. M., de HaAS, C. G. M., WISSERHOF, T. A., AND VAN GOLDE, L. M. G. (1978) FEBS Lett. 90, 57-60.

44. Soler-Argilaga, C., Russell, R. L., aND HEIMBERG, M. (1978) Arch. Biochem. Biophys. 190, 367-372.

45. Ontko, J. A. (1972) J. Biol. Chem. 247, 17881800.

46. INFANTE, J. P. (1977) Biochem. J. 167, 847-849.

47. SCHNEIDER, W. J., AND VANCE, D. E. (1978) Eur. J. Biochem. 85, 181-187. 